\title{
Environmental assessment of PSS, feedback on 2 years of experimentation
}

\author{
Romain Allais $^{1,2,{ }^{*}}$ and Julie Gobert ${ }^{3,4,5}$ \\ 1 Apesa Innovation, Pôle de Coopération Territorial, 23 rue Hélène Boucher, 40220 Tarnos, France \\ 2 PACTE, Université Grenoble Alpes, CNRS UMR 5194, Grenoble, France \\ 3 Laboratoire AMUP, INSA de Strasbourg, Strasbourg, France \\ ${ }^{4}$ LEESU, École Nationale des Ponts et Chaussées, 77455 Marne-La-Vallée, France \\ ${ }^{5}$ Lab'Urba, Université Paris Est, Paris, France
}

Received: 28 June 2017 / Accepted: 7 February 2018

\begin{abstract}
This communication details the sustainability assessment of the partial transition of business model from selling products to product renting for small household equipment (SHE). Perceived by the French SHE manufacturer as a strategic opportunity to meet customers' expectations and environmental regulation, 2-years experimentation was performed on a specific territory with the support of a network of new competencies (B-to-B-to-C market). Researchers were mandated for the sustainability assessment of such a transition but this communication focuses on the environmental performance of the experimentation. The results of the comparative LCA are presented and the main environmental impacts linked to this business model transition are specified and discussed. Then, different eco-design scenarios are explored and recommendations for this specific case are proposed.
\end{abstract}

Keywords: LCA / PSS / ecodesign / end-of-life scenario

Résumé. Cette communication détaille l'évaluation de la durabilité de la transition partielle d'un modèle de vente de produits à leur location pour les petits équipements ménagers (PEM). Perçu par le fabricant français comme une opportunité stratégique pour répondre aux attentes des clients et à la réglementation environnementale, une expérimentation de 2 ans a été effectuée sur un territoire spécifique grâce au soutien d'un réseau de nouvelles compétences (marché B-to-B-to-C). Les chercheurs ont été mandatés pour l'évaluation de la durabilité d'une telle transition, mais cette communication se concentre sur la performance environnementale de l'expérimentation. Premièrement, les résultats des ACV comparatives sont présentés et les principaux impacts environnementaux liés à cette transition du modèle d'affaire sont précisés et discutés. Ensuite, différents scénarios d'écoconception sont explorés et des recommandations pour ce cas spécifique sont proposées.

\section{Introduction}

This communication proposes a feedback on 2-years experimentation on the partial transition from a conventional business model to a sustainable business model (SBM). Osterwalder and Pigneur [1] describe a BM as a "conceptual tool to help understand how a firm does business and can be used for analysis, comparison and performance assessment, management, communication, and innovation" while Chesbrough and Rosembloom [2] define a business model as "a mediator between the technical and the economic domains". Conventional

\footnotetext{
* e-mail: romain.allais@apesa.fr
}

business models are anchored in the shareholder vision of the firm while SBM are in line with the stakeholder theory (i.e. "Certainly shareholders are an important constituent and profits are a critical feature of this activity, but concern for profits is the result rather than the driver in the process of value creation" [3]). SBM "align interests of all stakeholder groups, and explicitly considers the environmental and society as key stakeholders" and it "capture(s) economic, social and environmental value for a wide range of stakeholders" [4].

\subsection{Motivations and objectives of the company}

The project leader, a French Small Household Equipment Manufacturer (SHEM) faces strategic issues for its business 
viability: increasing production costs (in material and labor), customer demand for more sophisticated products (even with decreasing purchasing power), and stricter WEEE regulations. More, SHE has an ambitious sustainable development policy and leads numerous research programs to reduce its impacts on the environment. It also proposes to its customer nutrition tips. Nevertheless, this sector is emblematic of resource overconsumption and mass production of Waste of Electrical and Electronic Equipment (WEEE).

To take advantage of these threats, the Eurêcook experimentation was launched to test the feasibility and viability of a transition from selling products to renting products. In fact, Product-Service Systems (PSS) is a tertiarization strategy of industrial companies to keep their competitiveness and survival thanks to new business development $[5,6]$. PSS are components of the functional economy, a "strategy aimed at decoupling economic growth and increasing consumption of natural resources" $[7,8]$ in $[9]$.

The ambition of SHEM is to develop a B-to-C product renting service for small household equipment. According to Tukker's PSS typology [10], product renting is described as "the product in general is owned by a provider, who is also responsible for maintenance, repair and control. The user pays for the use of the product. The main difference to product leasing is, however, that the user does not have unlimited and individual access; others can use the product at other times. The same product is sequentially used by different users."

The transition from selling products to product renting implies a complete revision of the business model of SHEM: key partners, key activities, key resources, value proposition, customer relationship, distribution channels and even customers segments. Costs and revenue streams also evolve and have to be redesigned (see [1] for more details on the business model canvas $^{\mathcal{O}}$ ).

\subsection{Objectives of the research}

Eurêcook is an action-research project divided into three steps:

- designing the service offer;

- experiment the service in a conurbation with a dynamic sustainability analysis and a social analysis (interviews with stakeholders and customers, customers' survey and direct observation);

- provide recommendations for the business model transition.

Researchers were involved in the second part of the process, during the experiment. They cannot influence the initial design phase.

In order to assess the sustainability potential of the transition, researchers developed a multidisciplinary method for sustainability assessment of servitization project. It is based on comparative Life Cycle Assessment (LCA) and the analysis of stakeholders' behaviour according to the sociology of organizations. The methodology and tools are presented in $[11,12,13]$.

This communication focuses on the results of the comparative LCA. This method was chosen because it is a reference method [14,15] often used to evaluate the environmental impact of product [16,17] and frequently used for PSS environmental assessment [18,19]. First, the service offer is detailed, then the comparative LCA is presented (perimeter, and scenarios), then the results are discussed.

\section{Environmental assessment of a dematerialization strategy}

\subsection{Structuration of the offer}

The value constellation (i.e. stakeholders involved to provide the service) is described in Table 1 (from [11]). SHEM proposes a large number of culinary SHE for renting, 28 devices were proposed at the beginning of the experiment (e.g. pop-corn machine, beer fountain, raclette or high-tech kitchen helpers). The customer reserves his device on a dedicated website developed by the software developer (SoftDev). The information system centralizes orders and associated logistic chain operated by an insertion company (InsCom) that delivers and recovers the devices from the distribution company (DisCom).

\subsection{Comparative LCA}

\subsubsection{Objectives and perimeter of the study}

The purpose of this LCA is to compare the environmental impacts of the Eurêcook service with a sales model. The results will make it possible to orientate the environmental improvements of the service offer (distribution, maintenance, etc.) in an iterative way during the experiment and then will be used to support the redesign of the products proposed for rental.

The study deals with the comparison of the environmental impacts of a small household appliance depending on whether it is leased through the Eurêcook service or purchased.

The object studied is a pancake machine and the rented appliances are the same appliances that are put on sale (the transport box was redesigned but the product for this experiment was not redesign of the product for this experiment). Consequently, the steps of extraction of the raw material and of manufacturing (components and assembly) will therefore be identical for the two systems to be compared. However, the use phase of the renting service is more complex than in the selling. In fact, there are additional life stages: delivery of the device to the users through the distribution company then take back to the insertion company for cleaning and quality reassurance. More, alternative scenarios for the end-of-life are also modeled and evaluated. Eurêcook service and alternative end-of-life scenarios are presented in Figure 1.

\subsubsection{Initial comparative LCA \\ 2.2.2.1 Initial models}

For this project, data collection for LCA was facilitated by a great responsivity of the partners of the project. Consequently, product's information (material, process, suppliers) are complete and reliable. More, the information 
Table 1. Life cycle steps, support function and related responsibility [11].

\begin{tabular}{ll}
\hline Steps of the life cycle & Stakeholder responsible for the task \\
\hline Extraction of raw materials & Producer's subcontractors (SHEM) \\
Design and production & Producer and project leader (SHEM) \\
Distribution/Renting & Retail chain (DisCom) \\
Use & Consumer \\
Cleaning & Firm specialized in social insertion of deprived persons (InsCom) \\
Storing/Transportation & Firm specialized in social insertion of deprived persons (InsCom) \\
Maintenance & Firm specialized in fixing appliances (subcontractor of SHEM) \\
End of Life & Producer (SHEM) \\
Support function & Public authorities \\
IT development and maintenance & Stakeholder responsible for the task \\
Observation and assessment & Specialized IT solution development firm (SoftDev) \\
\hline
\end{tabular}

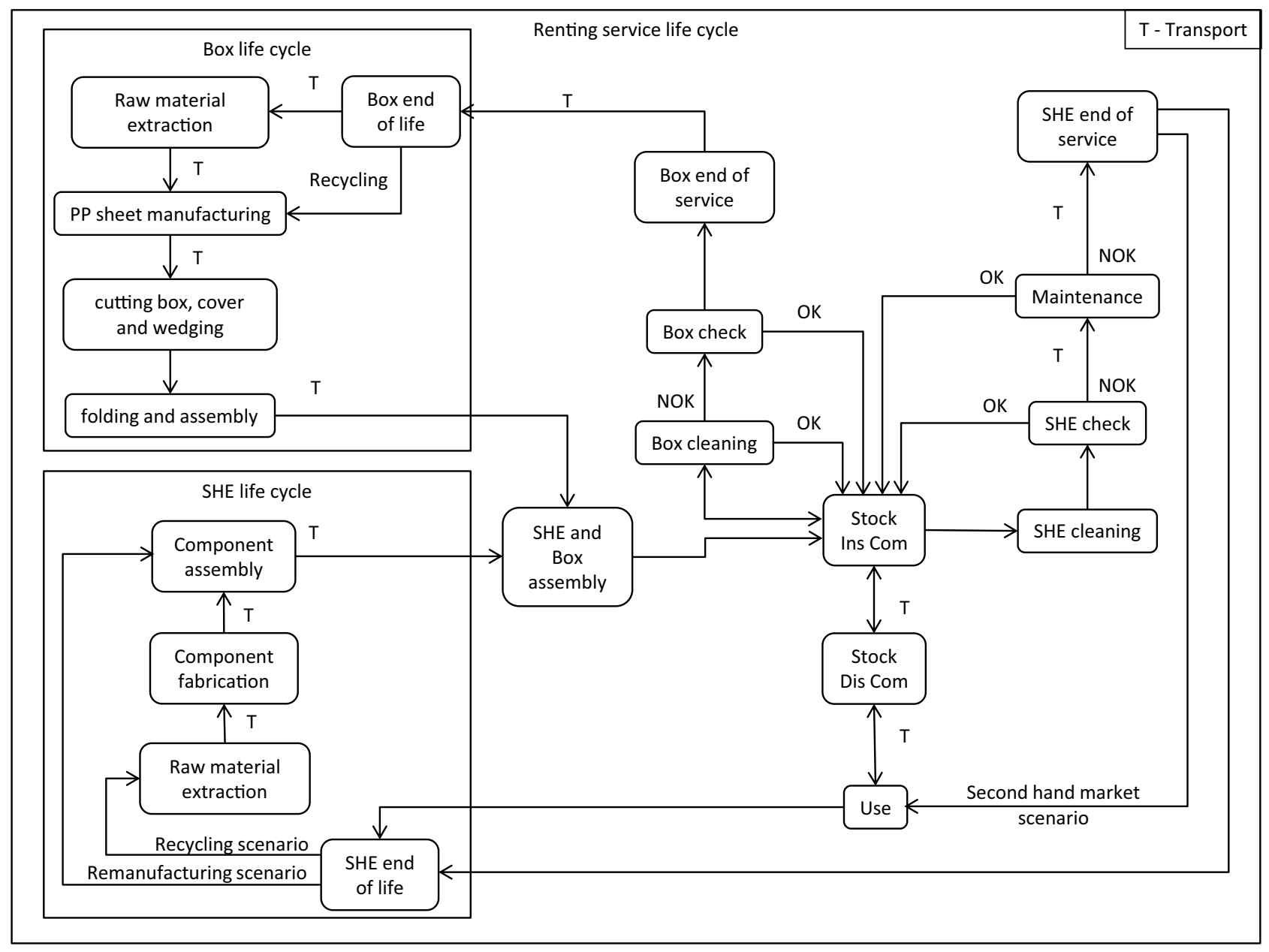

Fig. 1. Eurêcook life cycle and alternative end-of-life scenarios.

system centralizes data from the field and provide environmental analyst with real data (customer and InsCom logistic, etc.). The detail of these data is not provided in this communication.
The environmental impacts studied were selected in accordance with the recommendations of the European Commission's Recommendations for LCIA in the European context [17]. The final choice of indicators should have 
Table 2. ILCD environmental indicators.

\begin{tabular}{cccc}
\hline Climate change & Ozone depletion & Particulate matter / respiratory inorganics & Land use \\
Human toxicity & Photochemical ozone formation & Acidification & Resource depletion \\
Ionizing radiation & Eutrophication & Ecotoxicity \\
\hline
\end{tabular}

been limited to 5 or 6 indicators relevant to the environmental impacts of the product/service and SHEM's environmental priorities. This reduction work has not been done yet: the comparison of sales and rental systems is carried out on all the indicators recommended by the ILCD (Tab. 2).

The functional unit was defined as follow: cook a quantity of crêpe batter (1 liter of milk, $500 \mathrm{~g}$ of sifted flour, 6 eggs, salt, and butter) or 60 mini-pancakes for 1 cycle. Environmental assessment was made for 400 cycles of use (i.e. initially 10 pancake machines for selling and renting).

\subsubsection{Results}

It is clear that the Eurêcook basic solution is more impacting than the selling on all indicators. The impacts of the rental service are 2 to 35 times greater than the impacts of the sales model (e.g. 18 for $\mathrm{CO}_{2}$ emissions).

For Eurêcook, the use phase is the most impacting on the entire service life cycle for all indicators (between 70 and 98\%). For some indicators, the impacts of the manufacturing phase become significant (20-25\%).

In the use phase, the journeys made by the client between his home and the relay point (DisCom) creates the impacts for all indicators. For two indicators (i.e. ionizing radiation, water consumption), water and electricity consumption contribute $25-30 \%$ to these impacts.

\subsubsection{Sensitivity analysis (service design)}

Sensitivity analysis is used when there is uncertainty about a given datum in the model (assumption) or to test design parameters to understand how they participate in environmental impacts and then propose pathways for redesigning the service by acting on these levers for eco-design.

A sensitivity analysis regarding different product design parameters have been performed but were not significant on the whole life cycle of the PSS. These parameters are listed in Table 3.

In this case, the service design parameters are much more sensitive than the product design parameters.

\subsubsection{Allocation rule for transport-related impacts}

The allocation rule for transport-related impacts (what share of the journey is made specifically to enjoy the service?). We therefore carried out this sensitivity analysis to assess the influence of this allocation rule on the environmental impacts of Eurêcook. As the experiment progressed, unexpected behaviors appeared, creating a rebound effect: some users of the service take the device, then learn about recipes and come back shopping especially to test these recipes.
Table 3. Sensivity analysis of product design parameters.

\begin{tabular}{lll}
\hline Technical & $\begin{array}{l}\text { Duration } \\
\text { of use }\end{array}$ & $\begin{array}{l}\text { Robustness of } \\
\text { the device }\end{array}$ \\
Aesthetical & Electric & Complexity of \\
obsolescence & consumption & the device \\
Early obsolescence & & \\
\hline
\end{tabular}

Table 4. Allocation rule for transport-related impacts.

\begin{tabular}{lll}
\hline & $\begin{array}{l}\text { Allocation } \\
\text { rules }\end{array}$ & $\begin{array}{l}\text { Number of } \\
\text { round trip }\end{array}$ \\
\hline Scenario100 & $100 \%$ & \\
Scenario50 & $50 \%$ & 2 \\
Scenario10 & $10 \%$ & \\
Rebound effect & $100 \%$ & 3 \\
\hline
\end{tabular}

Four scenarios are detailed in Table 4, the average measured distance is about $16.3 \mathrm{~km}$ between customers' house and relay point ( $80 \%$ of the customers take their car) and the average distance for the store supply is about $28 \mathrm{~km}$.

In each case, the Eurêcook proposal is more impactful than the sales model. The rule for the allocation of the impacts of home-to-relay transport is a sensitive criterion, but it is not a criterion for the design of the service: it is a measure from the field. The realistic range for experimentation is around $70-90 \%$. Indeed, nearly $80 \%$ of customers went to the Drive (so necessarily by car). In addition, interviews show that the paths are made specifically to search for the device, or that an additional path (rebound effect) is realized and worsens this balance.

\subsubsection{Design parameters of the supply chain}

A sensitivity analysis was performed on the design parameters of the supply chain:

- Customer distance: 2 round trips between home and relay points in average car. This is a service design parameter linked to the territory meshing (locations of the relay points);

- Supply_distance: this design parameter is also linked to the territory meshing (location of the relay points) and it is a parameter for the design of the supply chain (size of buffer stocks, triggering of the tour etc.);

- Vehicle type: mode of transport used for customer logistics (home-to-relay routes). The type of vehicle is not directly a design data of the service but the design choices made in the service influence the type of transport of the customer: the size of the box imposes to move by car. 
Table 5. Sensivity analysis of the supply chain design parameters.

\begin{tabular}{|c|c|c|c|c|}
\hline \multirow[t]{2}{*}{ Scenario } & \multicolumn{4}{|c|}{ Parameters } \\
\hline & Vehicle type & $\begin{array}{l}\text { Customer } \\
\text { distance }\end{array}$ & $\begin{array}{l}\text { Supply } \\
\text { distance }\end{array}$ & $\begin{array}{l}\text { Impact } \\
\text { name }\end{array}$ \\
\hline Reference scenario (selling) & Car, average & 25 & 0 & Is \\
\hline \multicolumn{5}{|l|}{ Eurêcook: Vehicle type parameter } \\
\hline Car & Car, average & & & Ivo \\
\hline Bus & Bus & 16.3 & 28 & $\mathrm{Ib}$ \\
\hline Non-motorized & Bicycle, pedestrian... & & & Inm \\
\hline \multicolumn{5}{|c|}{ Eurêcook : Territory meshing parameters (Customer_distance, Supply_distance) } \\
\hline Car, Multiplication of relay points & Car, average & 5 & 50 & Imvo \\
\hline Non-motorized, Multiplication of relay points & Bicycle, pedestrian... & 5 & 50 & Imnm \\
\hline Home delivery & - & - & 80 & Idom \\
\hline
\end{tabular}

However, alternative transports are tested (bus, nonmotorized) but are not realistic in view of the current size of the box.

Six scenarios based on his parameters are detailed in Table 5.

For the sensivity analysis of the vehicle type parameter, impacts of the Eurêcook service are greater than or equal to the impacts of the sales model for all indicators, whatever the scenario. On the whole of the indicators, the impacts of the non-motorized scenario are substantially equal to those of the sales model $(1.45>\mathrm{Inm} / \mathrm{Is}>0.93)$. The bus scenario is systematically higher $(1.28>\mathrm{Ib} /$ Is $>47.73)$ and the car scenario much higher $(2.12>$ Ivo / Is $>63.67$ ).

Regarding the territory meshing parameters, it is clear that the Customer distance parameter is the paramount parameter for all the environmental impacts of the service. The multiplication of relay points significantly improves the impact of the service offer (Ivo / Imvo $\approx 3$ ) for all the indicators. The environmental benefits of decreasing the Customer distance parameter are considerably higher than those resulting from the degradation of the Supply distance parameter (multiplication of relay points and home delivery). The environmental impacts of scenarios 'non-motorized, multiplication of relay points' and 'Home delivery' are substantially equivalent to the impacts of the sales model. The 'non-motorized, multiplication of relay points' scenario is slightly less significant than the 'home delivery' scenario: $0.96>\mathrm{Imnm} / \mathrm{Is}>2.14 ; 1.00>\mathrm{Idom} / \mathrm{Is}>2.32$ but the deviations at this level are not significant.

\subsubsection{Discussion}

The first comparative analysis shows that the product renting service Eurêcook create much more impacts on the environment due to the multiplication of displacements. The expected sustainability of the PSS is not reached for the environmental purpose. Sensivity analysis highlights the importance of the service design parameters: customer_distance $>$ vehicle_type $>$ supply_distance.

\subsubsection{End-of-life scenarios (Business model design)}

In this part, we explore different end-of-life scenarios directly influenced by the product renting business model. SHEM remains the owner of the rented appliances, the constraints on the design process is to lengthen the lifetime of the objects according to different strategies (e.g. robustness, maintenance, remanufacturing, upgradability) and revenues are smoothed over the life of the product and other factors of value creation may be proposed (e.g. advice, associated services, etc.). SHEM did not provide information on the business model set up for this experiment; we explore the different end-of-life scenarios and associated product design strategies without the possibility of assessing their economic viability.

First, different scenarios for the end-of-life are presented in Table 6. Two scenarios are based on ADEME's WEEE data (professional/domestic WEEE). Other scenarios are second-hand market (i.e. end of use for aesthetic reason for example, the device is sold via second hand shop as InsCom), the remanufacturing scenario consists in maintaining the product with new or dismantled components from used devices. The last scenario is the traditional material recycling.

For these scenarios, a material input/output analysis and environmental impact assessment were performed (Fig. 2). Customer_distance and Supply_distance were suppressed in order to be able to see evolution between the scenarios.

For this I/O balance, the reuse solutions of the devices/ boxes or components are more interesting than the basic scenario (industrial WEEE). But these results are only informative and must be compared with the actual technical and economic possibilities in terms of dismantling and reverse logistic chain. The adoption of one or the other (or the combination of) the scenarios presented above must be accompanied by the implementation of a method of redesign dedicated to the chosen strategy and a study of the associated business model. Methods developed in the design sciences are useful for this project: design for disassembly, design for material recycling, design for remanufacturing, design for upcycling for example 
Table 6. End-of-life scenarios.

\begin{tabular}{lllllll}
\hline \multirow{2}{*}{ Scenario } & \multicolumn{4}{c}{ End-of-life treatment } \\
\cline { 3 - 6 } & & Device reuse & Part reuse & Recycling & Incineration & Landfill \\
\hline \multirow{2}{*}{ Ademe $^{\mathrm{a}}$} & Professional WEEE & $19 \%$ & $1 \%$ & $69 \%$ & $5 \%$ & $7 \%$ \\
\multirow{3}{*}{ End-of-life scenarios } & Domestic WEEE & $1 \%$ & $1 \%$ & $78 \%$ & $8 \%$ & $12 \%$ \\
& 2nd hand market & $80 \%$ & & & $10 \%$ & $10 \%$ \\
& Remanufacturing & & $80 \%$ & & $10 \%$ & $10 \%$ \\
& Material recycling & & & $80 \%$ & $10 \%$ & $10 \%$ \\
\hline
\end{tabular}

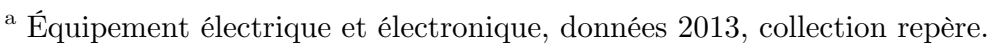

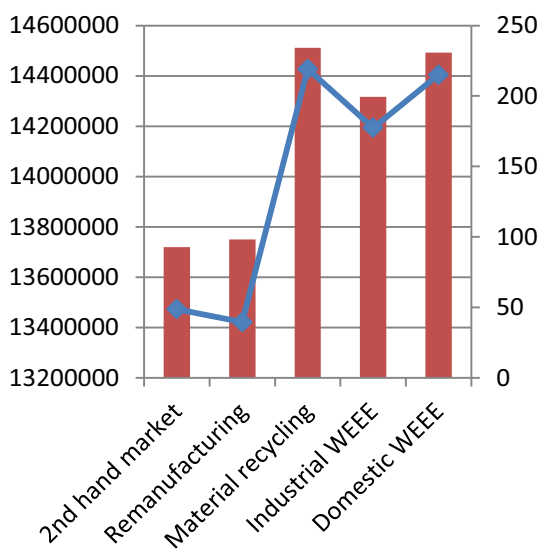

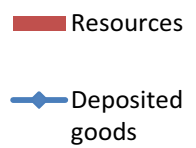

Fig. 2. I/O analysis and environmental impacts of end-of-life scenarios.
$[20,21,22]$. More, it should be noticed that beyond the environmental impacts, the proposed scenarios must be thought of as business opportunities. These end-of-life strategies will also have an impact on the value proposition of the service and its profitability (cost of supplying new machines/components vs. remanufacturing costs or aesthetic obsolescence costs vs. second-hand supply revenues for example).

\subsubsection{Leasing scenario}

Based on the previous environmental assessment results, we recommend revising the PSS type and proposing a product leasing qualified in [10] as "the provider has ownership, and is also often responsible for maintenance, repair and control. The lessee pays a regular fee for the use of the product; in this case normally he/she has unlimited and individual access to the leased product." The long-term lease scenario reduces the impact of customer logistics because it does not make a journey for each use of the service. This type of scenario must be tested for devices with a particular profile:

- Frequent use: the device is used potentially several times a week at the customer: banish from this offer devices for punctual use;

- Large purchase cost: the barrier to entry created by the price of the aircraft will be eliminated by the long-term lease.

For the long-term lease scenario with preventive maintenance for a complex device, the environmental impacts of the leasing service $\left(\mathrm{I}_{\text {lease }}\right)$ are lower than the impacts of the sale $\left(\mathrm{I}_{\mathrm{s}}\right)\left(0.18<\mathrm{I}_{\text {lease }} / \mathrm{I}_{\mathrm{S}}<0.57\right)$. This proposal eliminates the customer logistics at each use and prevent product obsolescence's (i.e. upcycling prevent for aesthetic and technological obsolescence and preventive maintenance for technical obsolescence). This value proposition may be submitted to a particular customer of the current service, identified as "pre-purchase tester". Long-term leasing mainly opens up business opportunities and the creation of shared value with the customers of the service and the partner companies needed to create the offer.

\section{Conclusion}

The environmental assessment of the product renting appears, for this particular case, significantly more impactful than the traditional sell of the same product. Service, product and business parameters were explored and the service design parameter customer distance linked with the territorial meshing appears as the most influential. The necessity to integrate the territorial dimension in PSS projects is well-described in [9] and also explored for sustainability purpose in $[23,24]$.

In-depth reflection on the business model and the collective governance and collaboration between the stakeholders of the value constellation should be undertaken in conjunction with product redesign and associated maintenance/upcycling. It is only through this integrated 
design approach that PSS projects can achieve its sustainability objectives. Eurêcook lacks this necessary collaboration and competencies to succeed: the design and management of the project was led by marketing services without consideration for external expertise and issues. The experiment shows that neither economic nor environmental or social/societal value was created. Consequently, even if PSS are classified as SBM, this experiment proves that the basic application of such SBM does not create exnihilo shared value for the diversity of stakeholders.

Both territorial and governance dimensions are considered in the interdisciplinary analytical framework codeveloped with Julie Gobert [13,25] based on the proximity theory and the hybridization of intellectual and territorial asset management frameworks. This analytical framework was developed during Eurêcook and will be tested and improved through new case studies.

Acknowledgements. The authors would like to thank the French Environment and Energy Management Agency (ADEME) for funding the project; Dominique Bourg, Bertrand Guillaume and Bertrand Laratte.

\section{References}

1. A. Osterwalder, Y. Pigneur, Clarifying business models: Origins, Present, and future of the concept, Communications of AIS, 2005

2. H. Chesbrough, R. Rosenbloom, The role of the business model in capturing value from innovation: evidence from Xerox corporation's technology spin-off companies, industrial and corporate change, Oxford university press, 2002, pp. $529-555$

3. R. Freeman, A. Wicks, B. Parmar, Stakeholder theory and "the corporate objective revisited", Organ. Sci. 15(3), 364 (2004)

4. N. Bocken, S. Short, P. Rana, S. Evans, A literature and practice review to develop sustainable business model archetypes, J. Clean. Prod. (2013) DOI: 10.1016/j.jcle pro.2013.11.039

5. A. Tukker, Product services for a resource-efficiency and circular economy - A review, J. Clean. Prod. 97, 76 (2015)

6. H. Meier, R. Roy, G. Seliger, Industrial product-service Systems-IPS2, CIRP Annals-Manuf. Tech. 59, 607 (2010)

7. D. Bourg, N. Buclet, L'économie de fonctionnalité. Changer la consommation dans le sens du développement durable, Revue futurible 313, (2005)

8. C. (du) Tertre, Économie de la fonctionnalité, Développement Durable et innovations institutionnelles, in: E. Heurgon (Ed.), Économie des services pour un Développement Durable l'Harmattan, Paris, 2007, pp. 142-255

9. N. Buclet, L'économie de fonctionnalité entre éco-conception et territoire: une typologie, Développement durable et territoires, 5(1), 2014 [En ligne]
10. A. Tukker, Eight types of product-service system: eight ways to sustainability? Experiences from SusProNet, Bus. Strategy Environ. 13(4), 246 (2004)

11. R. Allais, J. Gobert, A multidisciplinary method for sustainability assessment of PSS: challenge and developments, CIRP J. Manuf. Sci. Tech. 15, 56 (2016)

12. J. Gobert, R. Allais, Cadre d'analyse interdisciplinaire des projets d'économie circulaire: représentations des territoires d'action et mobilisation des capitaux, conference ASRDLF2016, Gatineau, QC, 2016

13. J. Gobert, R. Allais, Intellectual and territorial capital for the sustainability assessment of a servitization project, 9th European Conference on Intellectual Capital, ECIC2017 conference, Lisbon, 2017

14. N.F. Nissen, H. Griese, A. Middendorf, J. Müller, H. Pötter, H. Reichl, Comparison of simplified environmental assessments versus full life cycle assessment (LCA) for the electronics designer, life cycle networks, in: Proceedings of the 4th CIRP International Seminar on Life Cycle Engineering, CIRP, Berlin, Germany, 1997, pp. 435-444

15. J. Valkama, M. Keskinen, Comparison of simplified LCA variations for three LCA Cases of electronic products from the ecodesign point of view, in: Proceedings of the 2008 IEEE International Symposium on Electronics and the Environment, ISEE'08, 2008, pp. 1-6

16. R. Horne, T. Grant, K. Verghese, Life cycle assessment: principles, practice and prospects, CSIRO Pub.9780643094529, 2009

17. ILCD. 2010, General Guide for Life Cycle Assessment Detailed guidance European Commission - Joint Research Centre - Institute for Environment and Sustainability, Office of the European Union

18. H.K. Chan, X. Wang, A. Raffoni, An integrated approach for green design: life-cycle, fuzzy AHP and environmental management accounting, Br. Account. Rev. 46, 344 (2014)

19. J.G. Vogtländer, A. Bijma, H. Brezet, Communicating the eco-efficiency of product and services by means of the ecocosts/value model, J. Clean. Prod. 10, 57 (2002)

20. F. Zhang, M. Rio, R. Allais, P. Zwolinski, T. Reyes, L. Roucoules, E. Mercier-Laurent, N. Buclet, Toward a systemic navigation framework to integrate sustainable development into company, J. Clean. Prod. 54, 199 (2013)

21. O. Pialot, D. Millet, Why upgradability should be considered for rationalizing materials? 21st CIRP conference for life cycle engineering, Procedia CIRO 15, 379 (2014)

22. N. Perry, S. Richet, 2013, Pré-projet de recherche collaboratif, bilan et évolutions des filières de recyclage des produits et matériaux dans les secteurs automobile, navale et aéronautique, ecoSD

23. R. Allais, T. Reyes, L. Roucoules, Inclusion of territorial resources in the product development process, J. Clean. Prod. 94, 187 (2015)

24. R. Allais, L. Roucoules, T. Reyes, Governance maturity grid: a transition method for integrating sustainability into companies? J. Clean. Prod. 140, 213 (2016)

25. J. Gobert, R. Allais, Under review, L'économie de la fonctionnalité et le défi de créer une proximité organisationnelle aux niveaux opérationnel et stratégique, RERU

Cite this article as: Romain Allais, Julie Gobert, Environmental assessment of PSS, feedback on 2 years of experimentation, Matériaux \& Techniques 105, 504 (2017) 